\title{
RHEOLOGICAL PROPERTIES OF ALUMINA CERAMIC SLURRIES FOR CERAMIC SHELL-MOULD FABRICATION
}

\author{
REOLOŠKE LASTNOSTI GOŠČE IZ GLINICE ZA IZDELAVO \\ KERAMIČNIH KALUPOV
}

\author{
Joanna Szymańska, Pawel Wiśniewski, Marcin Małek, Jarosław Mizera \\ Warsaw University of Technology, Faculty of Materials Science and Engineering, Woloska Street 141, 02-507 Warsaw, Poland \\ joanna.szymanska.pl@gmail.com \\ Prejem rokopisa - received: 2015-07-01; sprejem za objavo - accepted for publication: 2015-09-15
}

doi:10.17222/mit.2015.188

\begin{abstract}
This research is about the properties of ceramic slurries prepared from hydrous nano-alumina-based binder and a corundum matrix used for fabricating the prime coat of ceramic shell moulds. Solid-state alumina powders with different granulations were used. The modification of the technological properties of the prepared slurries was based on additions of a polyacrylic binder with different amounts of polymer with respect to the alumina for different powder ratios. The slurries were prepared and tested in a mechanical mixer. During the slurry preparation (within $96 \mathrm{~h}$ ), the plate weight, Zahn cup 4\# viscosity and dynamic viscosity were controlled. The morphology and chemical properties of corundum powders and polymer were characterized with SEM and powder-grain-size distribution. The obtained results of the corundum-based ceramic slurries indicate that the application of a polymeric binder with various concentrations based on nano-alumina oxides causes different properties in comparison to the other commonly used binders.
\end{abstract}

Keywords: ceramic slurries, investment casting, shell moulds, alumina powder

Raziskava obsega lastnosti keramičnih gošč, pripravljenih iz nanogliničnega veziva na vodni osnovi in korundne osnove, uporabljenih za prvo prevleko pri izdelavi keramičnih tankostenskih form. Uporabljen je bil prah glinice $\mathrm{v}$ trdnem stanju, $\mathrm{z}$ različno zrnatostjo. Spreminjanje tehnoloških lastnosti pripravljene gošče je temeljilo na dodatku poliakrilnega veziva z različno vsebnostjo polimerov, glede na glinico pri različnih razmerjih praha. Gošče so bile pripravljene in preizkušene v mehanskem mešalniku. Med pripravo gošče (v okviru 96 h), je bila kontrolirana teža plošč, viskoznost 4\# z Zahn potopnim viskozimetrom in dinamična viskoznost. Morfologija in kemijske lastnosti korundnih prahov in polimerov so bile določene s SEM in $z$ razporeditvijo velikosti zrn. Dobljeni rezultati keramičnih gošč na osnovi korunda kažejo, da se z uporabo polimernega veziva in različne koncentracije nanoglinice, doseže različne lastnosti v primerjavi s standardno uporabljanimi vezivi.

Ključne besede: keramična gošča, precizijsko litje, tankostenska forma, glinica v prahu

\section{INTRODUCTION}

The investment-casting process is commonly applied in the manufacturing of the materials for the aviation, energy and military industries. The limiting components (flight safety parts) such as aircraft turbine blades characterized by complicated shapes are cast with the Bridgman method. ${ }^{1}$ A commonly applied technique is the lost-wax processing including the use of ceramic shells. It determines the precise shape, dimensional accuracy, appropriate structure and metallurgic purity of designed parts. So far, ceramic shell moulds were fabricated on the basis of colloidal silica. However, the presence of $\mathrm{SiO}_{2}$ in the prime coat during the $\mathrm{Ni}$ - or Co-superalloy casting causes a reaction with the liquid metal at a high temperature, inducing an oxidation of the reactive metal such as $\mathrm{Hf}$. Such an adverse phenomenon reduces the quality of the properties of cast parts, affecting its exploitation time. ${ }^{2}$

The basic components for a ceramic slurry are binders and fillers in the form of ceramic powders and supportive materials. A commonly used binder is hydrolyzed tetraethylorthosilicate together with organic com- pounds of silicon. ${ }^{3}$ However, pure ethyl silicate does not have the binding capacity. Water-based binders dry more slowly than alcohol-based ones. Consequently, there is a time elongation enabling the control of the surface smoothness, permeability, strength and dimensional stability of the model. ${ }^{4,5}$

A proper selection of powder for ceramic shell moulds and their parameters such as the kind, shape and size of particles affect the final characteristics of the cast elements. ${ }^{6}$ Ceramic powders present a thermal resistance, a slight thermal expansion and a lack of polymorphic transitions.

Deflocculants, softeners and surfactants mainly determine the rheological properties of ceramic slurries. ${ }^{3}$

It was found that a nano- $\mathrm{Al}_{2} \mathrm{O}_{3}$-based binder does not react with $\mathrm{Ni}$-alloy components. Moreover, such a binder demonstrates a higher melting point and a larger surface area than other inorganic solvents. It is also characterized by an improved dispersion of the particles in water, thus allowing the control of rheological properties by preventing the sedimentation of heavy particles in a ceramic slurry. 6,7 This is why such a binder can be applied instead of the colloidal silica-based binder. 
The main aim of the following research was to examine and define the properties of a nano-aluminumoxide-based binder and a corundum matrix using a polymeric binder with various concentrations.

\section{MATERIALS AND EXPERIMENTAL METHODS}

The subject of this research was a powder of $\mathrm{Al}_{2} \mathrm{O}_{3}$ with granulation of $0-30$ and 200 mesh (Treibacher) characterized by the average size of 11.79 and $45.00 \mu \mathrm{m}$, respectively. Solvent, binder and a hydrous polymer were dispersed in colloidal $\mathrm{Al}_{2} \mathrm{O}_{3}$ with a particle size of $16 \mathrm{~nm}$ (Imerys, Evonik). The additive material applied to modify the rheological properties of the slurry was a poly acrylic polymer (Imerys, Evonik).

Ceramic slurries with a solid phase content of $72.5 \%$ by weight and polymer amounts of $(6,10,15) \%$ mass fractions with respect to the alumina for different powder ratios of 35:65 and 65:35 (200:030 mesh) were prepared in a mechanical mixer within $96 \mathrm{~h}$ with a speed of $160 \mathrm{~min}^{-1}$. During the slurry preparation, the $\mathrm{pH}$ (with the use of a pH meter), plate weight and Zahn cup 4\# viscosity were checked every $24 \mathrm{~h}$. These measurements are fundamental for the investment-casting industry. After $96 \mathrm{~h}$ of mixing, rheological properties such as dynamic viscosity were also defined with a Brookfield $D V$-II rheometer with the spindle rotating in a speed range of 1-200-1 $\mathrm{min}^{-1}$. All the measurements were taken in an air-conditioned lab at $21{ }^{\circ} \mathrm{C}$.

To characterize the morphology of the corundum powders and the polymer, SEM images were taken with a Hitachi SU70 scanning electron microscope and a BSE detector at a voltage of $5 \mathrm{kV}$. A particle-size test was done using a Horiba LA-950 laser diffraction device (Hitachi, Japan).

The plate test was based on immersing the plate $(7.5 \times 7.5 \mathrm{~cm})$ in the moulding mass and estimating its weight after $120 \mathrm{~s}$.

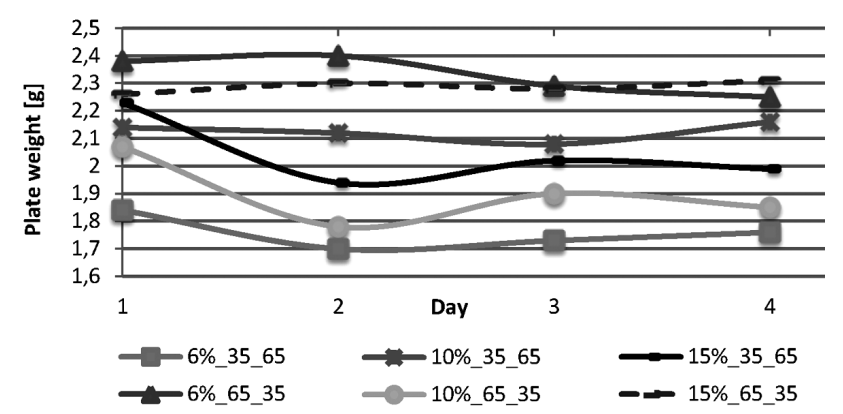

Figure 1: Relation between plate weight and stirring time for ceramic slurries with solid-content mass fraction of $72.5 \%$ for different polymer contents at 35:65 and 65:35 powder ratios (200:030)

Slika 1: Razmerje med težo plošče in časom mešanja gošče z vsebnostjo 72,5 \% trdnega masnega deleža, pri različnih vsebnostih polimera in razmerju prahov 35:65 in 65:35 (200:030)

\section{RESULTS AND DISCUSSION}

The morphology of the powder based on the SEM analysis of \#200 and \#0-30 indicated typical structures of molten powders with angular-shaped particles.

The obtained results shown on Figure 1 prove that the lowest plate values correspond to $6 \%$ of mass fractions of the polymer content for a powder ratio of 35:65. The largest ones were noticed for the slurries with 6 and $15 \%$ of mass fractions of the polymer content at a proportion of 65:35. The highest plate stability was obtained for the slurries with $15 \%$ of mass fractions of polymer addition (65:35) and $10 \%$ of mass fractions of polymer content $(35: 65)$. The values of the plate weight controlled on the last days of the measurements were in a range of 1.7-2.4 g. The measurements of the plate weight revealed a correlation with the polymer content: a $6 \%$ of mass fraction of the polymer addition resulted in the highest weight value, equal to $2.40 \mathrm{~g}$; this value was slightly lower in the case of a $15 \%$ of mass fraction of the polymer content and the lowest for a $10 \%$ of mass fraction of the polymer amount.

Zahn Cup 4\# measurements showed (Figure 2) the lowest values (13-15 s) for the slurry with the $6 \%$ of mass fraction of the polymer at the 35:65 ratio. The highest viscosity was noticed for the slurry with the $15 \%$ of mass fraction at a powder ratio of 65:32. In this case, there was also a rapid viscosity change from $32 \mathrm{~s}$ (noticed on the first day) to $21 \mathrm{~s}$ after $96 \mathrm{~h}$. The viscosity was stable during the whole ceramic-slurry preparation process for 6 (at 65:35) and $10 \%$ of of mass fractions (at 35:65).

The obtained results shown on Figure 3 indicate stability of all the measured slurries within the measurement time. The lowest values were noticed for the slurries with $10 \%$ of mass fractions of the polymer content at the 65:35 ratio and for 6 of $\%$ of mass fractions of the polymer addition at the 35:65 powder proportion. The thickness values estimated after $96 \mathrm{~h}$ oscillated from 0.12 to $16 \mathrm{~mm}$. Moreover, the slurries

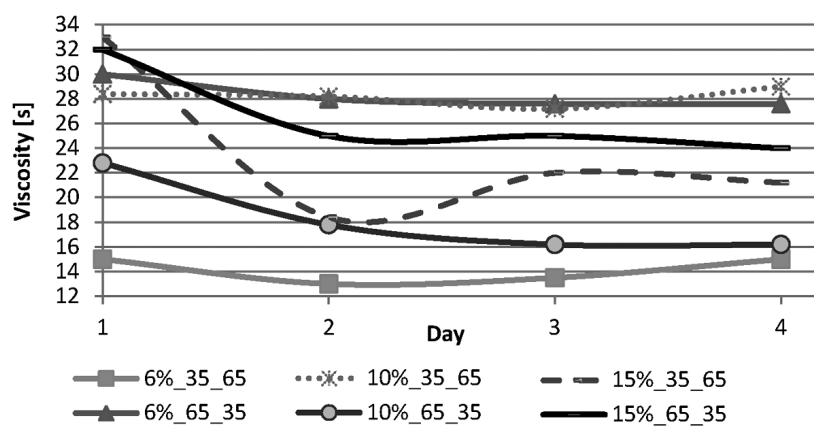

Figure 2: Relation between Zahn cup 4\# viscosity and stirring time for ceramic slurries with $72.5 \%$ of mass fractions of solid content for different polymer contents at 35:65 and 65:35 powder ratios (200:030) Slika 2: Razmerje med Zahn viskoznostjo 4\# in časom mešanja keramične gošče z 72,5 \% trdnega masnega deleža, pri različni vsebnosti polimera in razmerju prahov 35:65 in 65:35, mreža (200:030) 


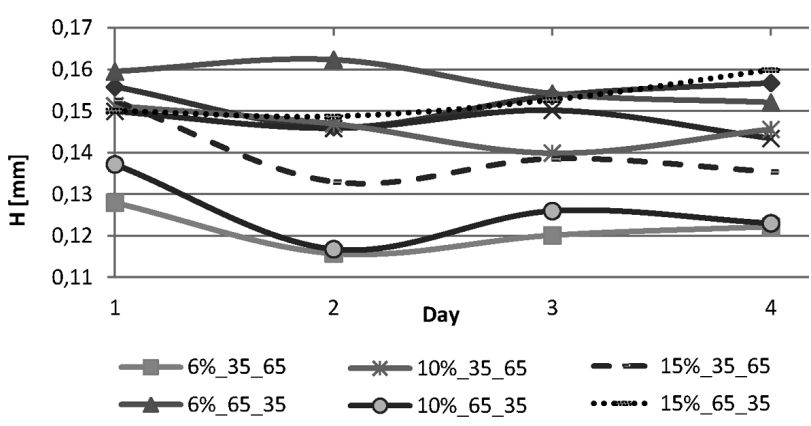

Figure 3: Coating thickness $(\mathrm{H})$ dependence on time for the slurries with $72.5 \%$ of mass fractions of solid content for $(6,10,15) \%$ of mass fractions of polymer content at two powder ratios, 35:65 and 65:35 (200:030 mesh)

Slika 3: Debelina nanosa $(\mathrm{H})$ v odvisnosti od časa pri gošči z 72, $5 \%$ masnim deležem trdnega in pri vsebnosti $(6,10,15) \%$ masnega deleža polimera, pri dveh razmerjih prahov $35: 65$ in $65: 35$, mreža (200:030)

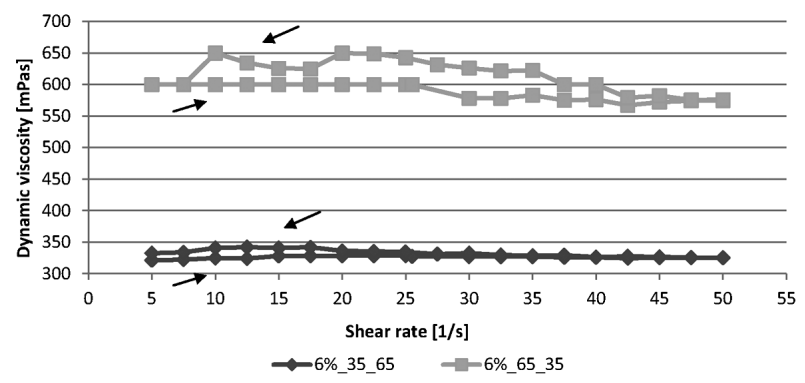

Figure 4: Relation between viscosity and shear rate of $\mathrm{Al}_{2} \mathrm{O}_{3}$ ceramic slurries with $72.5 \%$ of mass fractions of solid content for $6 \%$ of mass fractions of polymer content at two powder ratios, 35:65 and 65:35 (200:030 mesh)

Slika 4: Odvisnost med viskoznostjo in strižno hitrostjo $\mathrm{Al}_{2} \mathrm{O}_{3}$ keramične gošče z 72,5 \% deležem trdnega pri $6 \%$ masnega deleža polimera, pri dveh razmerjih zrnatosti prahov $35: 65$ in $65: 35$, mreža (200:030)

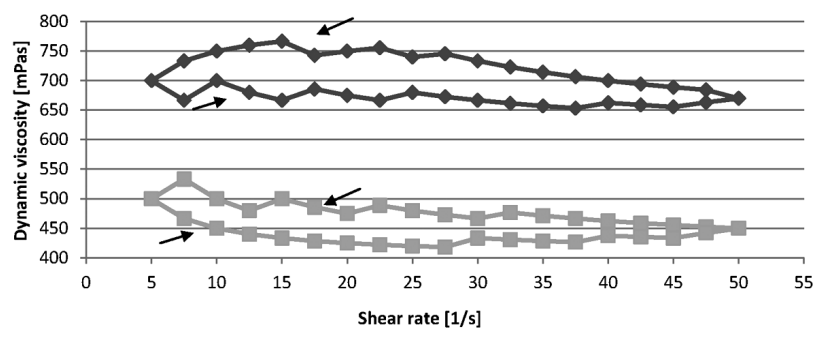

$\rightarrow 10 \%$ 35_65 $\rightarrow-10 \%$ _65_35

Figure 5: Relation between viscosity and shear rate of $\mathrm{Al}_{2} \mathrm{O}_{3}$ ceramic slurries with $72.5 \%$ of mass fractions of solid content for $10 \%$ of mass fractions of polymer content at two powder ratios, 35:65 and 65:35 (200:030 mesh)

Slika 5: Odvisnost med viskoznostjo in strižno hitrostjo $\mathrm{Al}_{2} \mathrm{O}_{3}$ keramične gošče z 72,5 \% masnim deležem trdnega pri $10 \%$ masnega deleža polimera, pri dveh razmerjih zrnatosti prahov 35:65 in 65:35, mreža (200:030)

with 6 and $10 \%$ of mass fractions of the polymer content were characterized as similar according to the viscosity level.

The measurements of the ceramic-slurry dynamic viscosity are shown on Figures $\mathbf{4}$ do $\mathbf{6}$ where the rela-

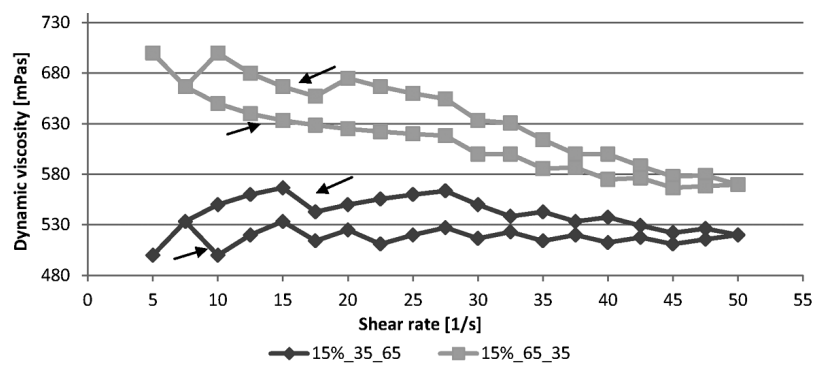

Figure 6: Relation between viscosity and shear rate of $\mathrm{Al}_{2} \mathrm{O}_{3}$ ceramic slurries with $72.5 \%$ of mass fractions of solid content for $15 \%$ of mass fractions of polymer content at two powder ratios, 35:65 and 65:35 (200:030 mesh)

Slika 6: Odvisnost med viskoznostjo in strižno hitrostjo $\mathrm{Al}_{2} \mathrm{O}_{3}$ keramične gošče z 72,5 \% masnim deležem trdnega pri $15 \%$ masnega deleža polimera, pri dveh razmerjih zrnatosti prahov 35:65 in 65:35, mreža (200:300)

tionship between the shear rate and viscosity is presented. As seen on the diagrams, additions of different concentrations of polymers to the ceramic slurries of $\mathrm{Al}_{2} \mathrm{O}_{3}$, with two powder ratios, determine their viscosity. The obtained results indicate that the application of $10 \%$ of mass fractions of polymer at the 35:65 powder ratio causes the largest increase in the dynamic viscosity where the maximum value is $763 \mathrm{MPa}$ s. The most effective was the addition of $6 \%$ of mass fraction of polymer at the 35:65 powder ratio resulting in the lowest dynamic-viscosity value of $321.12 \mathrm{MPa}$.

\section{CONCLUSION}

The $\mathrm{Al}_{2} \mathrm{O}_{3}$ powder characterized by irregularly shaped particles with sharp edges demonstrates the ability to agglomerate, resulting in a non-uniform particle-size distribution. The Zahn cup viscosity (7.35 s) is slightly larger in comparison to water viscosity (5.83 s), thus the $\mathrm{Al}_{2} \mathrm{O}_{3}$ particle dispersion in the binder is facilitated.

In addition, a relatively large content of the solid phase in a slurry reduces the coat shrinkage during the drying process and enhances its strength. The properties of the coating surface may be improved by increasing the plate weight. An addition of a poly acrylic polymer at the lowest content to the alumina powders with various granulation values allows a regulation of the rheological properties of the ceramic slurry towards more effective ceramic shell-mould fabrication.

The investigated slurries show standard features in the investment-casting process on an industrial scale. They are prospective for future shell-mould fabrication.

\section{Acknowledgement}

The financial support from the Structural Funds for the Operational Programme Innovative Economy (IE OP) provided by the European Regional Development Fund - Project "Modern material technologies in aero- 
space industry", Nr POIG.01.01.02-00-015/08-00, is gratefully acknowledged.

\section{REFERENCES}

${ }^{1}$ S. Roskosz, Relationship between mould's technology and structure of investment cast nickel based superalloys, Inżynieria Materiałowa, 29 (2008) 4, 375-379, doi:bwmeta1.element.baztech-articleBPL8-0006-0070

${ }^{2}$ H. Matysiak, J. Ferenc, J. Michalski, Z. Lipiński, G. Jakubowicz, K. J. Kurzydłowski, Porosity and strength of ceramic shell moulds used in investment casting process by Bridgman method, Inżynieria Materiałowa, 32 (2011) 1, 17-21, doi:bwmetal.element.baztechcle4cb00-4f01-476e-8401-81df9ad0e967
${ }^{3}$ J. Raabe, E. Bobryk, Functional Ceramics, Oficyna Wydawnicza Politechniki Warszawskiej, 1997

${ }^{4} \mathrm{R}$. Haratym, Investment casting processes for ceramic shell moulds, Warszawa 1997

${ }^{5}$ S. Jones, C. Yuan, Advances in shell moulding for investment casting, Journal of Materials Processing Technology, 135 (2003) 2-3, 258-265, doi:10.1016/S0924-0136(02)00907-X

${ }^{6}$ M. Zagórska, P. Wiśniewski, H. Matysiak, K. Kwapiszewska, J. Ferenc-Dominik, J. Michalski, K. J. Kurzydłowski, The influence of polymer binder, based on nano- $\mathrm{Al}_{2} \mathrm{O}_{3}$ dispersion, on the properties of ceramic slurries used in the investment casting, Euromat, 2011

${ }^{7}$ M. R. Ismael, R. D. Dos Anjos, R. Salomao, V. C. Pandolffelli, Colloidal silica as a nanostructured binder for refractory castables, Refractories Applications and News, 11 (2006) 4, 16-20 